\title{
「筑後久留米藩の英学」補遺
}

吉村 駿夫

\section{補速. 長崎留学者}

幕末から明治にかけて隣藩の福岡藩は数十名の留学生を長崎に送り，その中から十名近 くを選抜して欧米に派遗した。それに比すると，久留米藩は正確なことは分らぬか以下の 僅か六名を長崎に送ったてとは八ッキりしている。

\section{A. 前 野 雅 門}

久留米藩士前野静馬の子で元治元年馬迴組として召しだされ，今井栄の開成方に勤務し たが更に今井の引立によって軍艦雄飛丸乗組員となり，航海術と洋学一般を研讃するため 三年間長崎に留学した。留学から㷌ると同艦副艦長，和泉丸乗組を経て久留米藩の最大艦 千歳丸籃長となったが、この頃になると一応北海の戦乱も収まっていた。

時代も变わり，乙の監は北海貿易を目的とした北海商社の一時侓船するところとなった が、事業は失敗に㷌して篮は筑㣪に㷌った。

当時久留米藩勤王派汇不稳の動きあるを察知した新政府は四條少将を長とする諸藩聯合 の軍を筑後に派遣したか，掃討不要とみて軍を近畿に回航することになったが，回航の大 任が彼に降りた。今井の恩恵を思って彼の心境は複雑であった。それでも無事大任を果た した。

明治四年の廃藩置県によって藩海軍も消减したので, 彼は艦を降り隣郡浮羽郡延寿寺村 で隐栖の生活を送ったが明治十六年六月没した。時に五十五才。

\section{B. 柘植善吾}

柘植については既に詳しく述へたので，更に再び詳述する要はない。

文久三年彼は十二才の時翻により長崎に学んだ。後述する安田順次と共に長崎英学塾 で勉強した。

慶応二年長崎の英人アストンが久留米を訪れて藩公に謁した時彼が通訳をした。しかし - 211 - 
英学这研究第19号

頑迷な勤王派は何を起こすか分らぬ不安な状態で彼の身辺騒然たるものがあった。彼もア ストンも彼の許嫁の兄で勤王派の板垣太郎の秘かな尽力によって久留米を離れることがで きた。後に彼は岡山の人で後に子爵になった花房義質と共に船貨の中にかくれて長崎から 米国に渡ったのである。父の伝八は公武合体派に属した廉で幽閉され，藩の公職から追放 された。善吾にお各めはなかった。

\section{C. 安田順次}

明治二年久留米藩の実権を握った勤王派は暗殺，切腹、刑死、入獄等の弾圧を以て公武 合体派を危境に陥れた。安田も又犠牲者の一人で自殺に追い込まれたのである。

被は藩の御手大工安田家の竹子で，今井栄一派派する開明主義者の一人であった。永 らく消息不明で謎とされていたが，鲁相は自殺である。

彼は柘植之共に長崎英学塾に学び，屡応三年柘植と共に米国に留学する筈であったが， 何故か取り止めとなった。今ではその謎は自ずと明白である。

彼の生家高木家には長崎時代の英語教科書多数が残っているが，勤王派暴虐の証拋物件 と言えよう。

\section{D. 竹 内 岩五郎}

慶応元年正月長崎で英語と洋算を学んだのを皮切りに, 各所で勉強した。慶応二年には 勝海舟の海軍伝習所で航海術，測量，算術を学び，そのあ之慶応義塾で福沢諭吉に就き英 語を修めた。

慶応四年四月藩海軍士官として藩艦千歳丸に乗組み北越征討に従事したが，明治五年二 月には新政府の海軍兵学智出仕之なって英語を教えた。又攻玉塾で数学を教えた。

又明治四年九月米藩医学校「好生館」の助教授となって英語を教えたこともある。 名は初め岩五郎，のち知幾と改めた。

\section{E. 細 見保}

安政五年八月十六日京町に生る。号盤谷。慶応二年藩校明善堂に入り, 明治八年官立長 崎師範学校に入学した。公立師範とは違い，こちらは文部省の直轄学校で内容も格式も数 段高い。

同十年卒業と共に久留米師範訓導となり以後各地の高等小学校長を歴任, 最後久留米高 
小校長になった。この頃より女子中等教育の急務なることを痛感し，高等女学校の開設に 力を注ぎ始めた。明治二十年設立が認可されると開校と同時に初代校長に任ぜられたが， その任に在ること二十二年，その間の努力と赤誠と熱意は誠に尊敬に価する。久留米教育 界の先覚者功労者である。

昭和十一年七十九才を以て没した。

\section{$F$. 長 沢 龟之助}

万延元年十一月二十二日生れ，竹开軒之号した。藩校明善堂，高良山神習舘に学んだあ と，長畸の官立師䡉学校に入った。明治十一年卒業上京。川北朝烸の数理書院に入り鋭意 数学を勉強した。その後陸軍御用挂となり陸軍教䢘団で数学を教えたり，陸軍用の数学教 科書の編䍘に当った。一方数理書院の生徒にも教えた。

陸軍を辞すると東洋英和の教員になり，やがて校長になったが，生徒に対して聖整講義 に出席することを强制するのを不当として異議を唱えた。議合わずして同校を去った。

その後専修大学講師になったことはあるが, 彼の本領は数学教科書の編纂と数学雑誌 「えつくす・わい」の刊行にあった。彼はこの二つに全力投球をし続けた。教科書は百種 以上に上り、雑誌は死ぬまで継䊦した。

和算にも精通したか，洋算が和算流に綎書であったのを彼が初めて横書にした。 洋算研究の必要から数ヶ国語を自分のものとしたが、特にフランス語に吅みであった。 漢学、書籍鬼集、謡曲、仕舞、太鼓など趣味は広かったが，何れも堂に入っていた。 昭和二年六十八才を以て没した。多摩墓地に横書の彼の墓がある。

\section{参考文献}
久留米市「先人の面影
同上溜米市誌
久留米医師会「久留米医師会史」
柘植六郎『柘植善韋畧伝』
浅野隄吉门柘植美吾伝了
同上涪荍学の府・好生舒」 


$$
\text { 英学史研究第19号 }
$$

篠 原 正一门明丵校祸革史」

伊奈健次宮本洋学校史」

東京都「東京都史紀要一東京の英学」

同上『開学明細調」

线野隄吉『十志士の面影一久留米潾文化事業史」

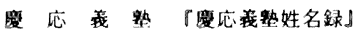

上田彰「長沢鲁之助者書目録」 